\title{
Students' Sport Activities During Covid-19 Pandemic Situation
}

\author{
Tri Rustiadi \\ \{trirustiadi@mail.unnes.ac.id\} \\ Universitas Negeri Semarang, Semarang, Indonesia
}

\begin{abstract}
Covid-19 pandemic in Indonesia forces the learning process at school to be carried out online. This study aims to determine student sports activities during the pandemic. This research is quantitative descriptive conducted at SMK Negeri 1 Tonjong, Brebes. The research sample was 459 students of XII grade. Data collection was gained through questionnaire technique with Google form. Data analysis used percentage descriptive analysis. The results showed that during the pandemic, $85 \%$ of students did sports activities and 15\% did not do sports activities. Sports activities in a week, $37 \%$ did it sometimes, 50\% 1-3 times. Time per sport activity, 86\% 0-60 minutes, 14\% 60-120 minutes. Types of sport activities are 5\% swimming, $65 \%$ athletics, $17 \%$ gymnastics, $2 \%$ biking and $11 \%$ jogging. The purpose of sports activities is $74 \%$ to maintain health. Sport activity places, $55 \%$ at home, $30 \%$ in public facilities. The conclusion is that during the Covid-19 pandemic, students continue to do sports activities with the aim of maintaining health.
\end{abstract}

Keywords: Activities, Sports, Pandemic, Covid-19

\section{Introduction}

Vocational High School (SMK) is an educational unit that provides vocational education at the secondary education level. Vocational education is a secondary education that prepares students, especially to work in certain fields [1]. The specific objectives of vocational education are: 1) Producing graduates who have competencies in accordance with the demands of the business world and the industrial world both nationally and globally, 2) Producing graduates who have vocational skills in technical expertise [2] programs that meet the competencies and certifications required by the world of work and professional associations in engineering that are relevant and able to compete in the global market, 3) Producing various research products and innovative programs in the PTK (vocational technology education) and technical disciplines that are useful for improving the quality of human resources in national development, 4) Becoming a center for information and dissemination in the fields of technology and vocational education as well as in the engineering field, 5) Producing many educators / trainers in the field of vocational technology who have an entrepreneurial spirit (entrepreneurship) [3].

In addition to having high competency to face the world of work, vocational students must also have good physical fitness, because physical fitness has a very big role for someone in carrying out the work they do. A person who has good physical fitness will have the ability to carry out daily activities effectively because he has enough fitness to be able to support core 
activities as well as additional daily activities. Without having a good level of physical fitness, a person will not be able to carry out activities and complete tasks properly.

Physical fitness is an important factor in carrying out daily activities in order to not experience excessive fatigue. According to physical fitness is the ability to perform daily tasks vigorously without feeling excessive fatigue and full of energy doing and enjoying activities in spare time that can face emergencies when it comes. In line with this, the definition of physical fitness according to [4]. Physical fitness is the capability and ability of the body to make adjustments (adaptations) to the physical liberation that is given to it (from daily work) without causing excessive fatigue. Physical fitness is the degree of dynamic health of a person whose basic physical ability is able to carry out tasks that must be carried out (5).

Physical Education Sports and Health is an integral part of the national education program, aims to develop some aspects of physical fitness, movement skills, critical thinking skills, social skills, reasoning, emotional stability, moral action, healthy lifestyles and the introduction of a clean environment through learning experiences using selected body activities that carried out systematically based on the values of faith and devotion to God Almighty. One of the competencies developed in the subject of Physical Education, Sports, and Health (PJOK) in Vocational Schools is the ability to analyze concepts and practice exercises, measuring components of physical fitness. From this competency, it is expected that students have the knowledge and ability to plan and carry out physical fitness activities and have the ability to measure the level of physical fitness. With this competency, it is hoped that vocational students will have good level of physical fitness which is certainly necessary when they have to face the world of work.

In early March 2020, positive cases of Covid-19 in Indonesia were first detected and on April 9, the Covid-19 pandemic had spread to 34 provinces in Indonesia. Responding to these conditions, at the end of March 2020 the Minister of Education and Culture issued Circular Letter Number 4 of 2020 concerning Implementation of Education Policies in the Emergency of the Spread of Corona Virus Disease-19 (COVID-19). In the circular, it is explained that the learning process is carried out at home through online learning. The learning process from home can be focused on life skills education, regarding the COVID-19 pandemic. This is one of the government's steps in an effort to break the rope of the spread of COVID-19 in Indonesia [6].

During the emergency period of the spread of Corona Virus Disease-19 (COVID-19), the learning process of physical education, sports and health cannot be carried out in schools. The implementation of Large Group Social Restrictions (PSBB) to break the chain of Covid-19 spread requires teachers to carry out WFH (work from home) in carrying out their duties as educators. The condition of teaching activities that suddenly changes drastically is a challenge for teachers, especially physical education, sports, and health (PJOK) teachers so that the goals and objectives of physical education, sports, and health can be achieved. Even though the Minister of Education and Culture circular letter no 4/2020 regarding learning guides at home during the pandemic period requires the teachers not to burden students through demands for curriculum achievement as class promotion requirements.

Physical education, sports, and health subject is very important subject for students to learn today, because with knowledge about health and sports practices students can fortify themselves, one of them is by increasing body resistance (immunity) to prevent corona virus, with regular exercise be one way to maintain health. In online learning, a physical education, sports, and health teacher must give assignments to the students so that they continue to do sports activities at home as part of physical education material that must be done at school. 
Twelfth grade vocational students will soon graduate and they must be ready to enter the world of work. During the emergency period of the spread of Corona Virus Disease-19 (COVID-19), they are expected to always foster their level of physical fitness by doing sports activities so that they have a good level of physical fitness. Based on the foregoing, it is necessary to conduct a scientific study, how do sports activities carried out by twelfth grade vocational students of SMK Negeri 1 in Brebes Regency in fostering a level of physical fitness during the Covid-19 pandemic?

\subsection{Covid-19}

Coronavirus Disease 2010 (COVID-19) is an infectious disease caused by Severe Respiratory Syndrome Coronavirus2 (SARS-CoV-2). SARS-CoV-2 is a new type of coronavirus that has never been previously identified in humans. There are at least two types of coronavirus known to trigger diseases that can cause severe symptoms such as Middle East Respiratory Syndrome (MERS) and Severe Acute Respiratory Syndrome (SARS). Common signs and symptoms of COVID-19 infection include acute respiratory symptoms such as fever, cough, breathless. The average incubation period is 5-6 days with the longest incubation period of 14 days. In severe cases of COVID-19, it can cause pneumonia, acute respiratory syndrome, kidney failure, and even death. Indonesia reported its first COVID-19 case on March 2, 2020 and the number continues to increase until now. As of 30 June 2020, the Ministry of Health reported 56,385 cases of COVID-19 convirmation with 2,875 deaths (CFR $5,1 \%$ ) spread across 34 provinces. As many as $51.5 \%$ of cases occurred in men. Most cases occur in the age range 45-54 years and the least occurs at the age of 0-5 years. The highest mortality rate was found in patients aged 55-64 years [7].

Coronavirus is a zoonotic (transmitted between animals and humans). Research states that SARS is transmitted from civet cats to humans and MERS from camels to humans. The animal that is the source of transmission of COVID-19 is still unknown. Based on current epidemiological and virological studies, it is proven that COVID-19 is mainly transmitted from symptomatic people to other people who are at close range via droplets. Droplets are water-filled particles with a diameter of $>5-10 \mu \mathrm{m}$. Droplet transmission occurs when a person is in close proximity (within 1 meter) of someone who has respiratory symptoms (for example, coughing or sneezing) so that the droplets are at risk of hitting the mucosa (mouth and nose) or the conjunctiva (eyes). Transmission can also occur through objects and surfaces contaminated with droplets around infected people. Therefore, transmission of the COVID-19 virus can occur through direct contact with an infected person and indirect contact with surfaces or objects used on an infected person (for example, a stethoscope or thermometer). In the context of COVID-19, airborne transmission may be possible in special circumstances where aeroson-producing supportive procedures or treatments such as endotracheal intubation, bronchoscopy, open suction, administration of nebulized medication, manual ventilation before intubation, turning the patient into a prone position, disconnecting the ventilator, moninvasive positive-pressure ventilation, tracheostomy, and cardiopulmonary resisutation. There is still a need for further research on airborne transparency. COVID-19 is a disease that attacks vital human organs, namely the lungs and until now a vaccine to prevent this disease is still being researched. One of the preventions is by implementing a healthy life and doing physical distancing. 


\subsection{Physical education, sports, and health}

Physical Education, Sports and Health (PJOK) can be defined as an educational process that utilizes physical activity to improve physical fitness, develop motor skills, get used to a healthy and active lifestyle, sportsmanship, and emotional intelligence. Physical education is part of education in general. Physical education is also an educational subsystem that has a role in developing human quality.

Physical Education, Sports, and Health (PJOK) learning is an inseparable part of general education. This learning is a place to interact in terms of kinesthetic intelligence. Physical Education, Sports, and Health (PJOK) is an integral part of education because it participates in educating the nation. Physical Education, Sports, and Health (PJOK) Physical Education, Sports, and Health (PJOK) has the goal 1) developing body organs to improve physical health and fitness 2) neuromuscular, 3) mental and emotional 4) social and 5) intellectual. The ultimate goal of Physical Education, Sports, and Health (PJOK) lies in its role as a unique vehicle for enhancing character, and as a vehicle to form a strong personality, good character and noble attitude in accordance with the goals of national education. Given the importance of physical education, sports and health in composing physiological and psychological students, it needs to be supported by various factors in the learning process [8].

Thus, Physical Education, Sports, and Health (PJOK) can be interpreted as an educational process that utilizes physical activity to improve physical fitness, develop motor skills, get used to a healthy and active lifestyle, sportsmanship, and emotional intelligence. Physical education is a part of education in general. Physical education is also an educational subsystem that has a role in developing human quality. Physical education, sports and health is the interaction of students with educators with learning resources in the form of physical activities, sports and health which curriculum is available in schools with the aim of guiding a completely healthy lifestyle. The provision of learning experiences is directed at fostering physical development, psychological development, motor skills, knowledge and reasoning, appreciation of values (attitudes, mental emotional, sportsmanship, spiritual, social) as well as fostering lifelong patterns of life, balanced physical and psychological development [9].

The real contribution of Physical Education, Sports, and Health (PJOK) is to develop skills (psychomotor). In this case, it can be said that Physical Education, Sports, and Health (PJOK) is a unique learning because it provides opportunities to build more skills than other subjects. The most important task in carrying out physical education is how to help students to be able to undergo the process of optimal growth and development both physically, motorically, mentally and socially(10). There are three important things that can be a unique contribution from learning physical education, namely (a) improving students 'physical fitness and health, (b) increasing the power of physical skills and (c) increasing students' understanding in principles as well as how to apply in practice [11].

\subsection{Physical fitness}

Physical fitness is an important factor in carrying out daily activities in order to not experience excessive fatigue. Physical fitness is the ability to perform daily tasks vigorously without feeling too tired and full of energy doing and enjoying activities in spare time that can face emergencies when it comes [2]. Physical fitness is the ability and ability of the body to make adjustments (adaptations) to the physical liberation that is given to it (from daily work) without causing excessive fatigue [12] . 
Physical fitness is the ability of a person to be able to do daily work efficiently without causing excessive fatigue so that he can still enjoy his spare time. Physical fitness gives a person the ability to carry out daily activities without excessive fatigue. This also means that a person still has energy reserves to enjoy his spare time to do sudden work properly. The bolder / fresher a person is, the greater their physical work ability and the less fatigue will occur [13].

Physical fitness is composed of various elements as indicators of overall physical fitness achievement. There are two aspects of physical fitness, namely physical fitness related to health and physical fitness related to skills. Physical fitness related to health includes: a) endurance of the heart and lungs; b) muscle strength; c) muscle endurance; d) flexibility; e) body composition. Physical fitness related to skills includes; a) speed; b) power; c) balance; d) agility; e) coordination; f) reaction speed [14]. There are several factors that can affect a person's physical fitness including 3 factors, namely nutrition, rest, and exercise [15].

There are many ways that people do to get physical fitness, for example by doing massage, taking a steam bath, and practicing sports. Exercising is one of the most effective and safe alternatives to physical fitness because it has multiple benefits, including physical benefits (increasing physical fitness), psychological benefits (more resistant to stress and better able to concentrate) and social benefits (it can increase self confidence, a medium of interacting and socializing). The other benefits of physical fitness training are increased strength and endurance to help carry out daily tasks because they don't tire quickly, exercise helps maintain heart and blood vessel health, good movement benefits the human body.

Physical fitness has many benefits, especially for carrying out daily activities. A body that has a good level of physical fitness will not tire easily so that activities can be carried out properly without any obstacles. Physical fitness functions in addition to showing physical condition can be divided into three. Physical fitness will bring benefits, those are, 1) developing muscle strength and endurance such as bone strength, joints which will support performance in both sports and non-sports activities; 2) Increasing aerobic resistance; 3) Increasing flexibility; 4) Burning calories which allows the body to avoid obesity; 5) Reducing stress; 6) Increasing passion for life [16].

\subsection{Sport activities}

According to the Indonesian Big Dictionary, activities are activities that are busy, active, work or one of the work activities carried out in each division of the organization or institution [17]. Sports are all systematic activities to encourage, foster, and develop physical, spiritual and social potential [18]. Sports can be defined as form of physical activity that is planned and structured by involving repeated body movements to get good results, for example to improve physical and spiritual fitness.

Sports can be grouped into modern sports and traditional sports. Modern sports include fencing, weightlifting, athletics, volleyball, basketball, biking, badminton, swimming, gymnastics, soccer. Traditional sports (native sports from several regions in Indonesia) include forts, stilts, tops, playing hadang, congklak [19].

Sports activities are activities or activities carried out by someone in a planned and structured manner by involving repeated body movements through sports (gymnastics, athletics, swimming, etc.) to get good results, for example to improve physical and spiritual fitness. 


\section{Methods}

This research is a descriptive quantitative study, using the survey-test method. The variables in this study were sports activities carried out by students of class XII SMK in Brebes Regency during the Covid-19 pandemic. The population in this study were all students of class XII SMKN 1 Tonjong Brebes Regency as many as 459 students. The research sample was taken by using the total sampling technique. The research data was taken using a questionnaire with google form format. Analysis of research data used percentage descriptive analysis.

\section{Result and Discussion}

\subsection{Result}

The results of research related to sports activities of class XII students of SMK Negeri Tonjong during the 2020 pandemic include: did students do activities during the pandemic?; sports activities carried out in the last 3 months; the number of sports activities in a week; time in any sporting activity; type of sports activity carried out; the purpose of doing sports activities; and four sports activities were carried out. The research results are presented in the following table:

Table 1. Sport activities during Covid-19 pandemic

\begin{tabular}{llrr}
\hline No & Sport Activities & Total & $\%$ \\
\hline 1 & During pandemic, do sport activities & 338 & 85 \\
2 & During pandemic, not do sport activities & 71 & 15 \\
\hline Total & & 459 & 100 \\
\hline
\end{tabular}

Based on table 1 above, it shows that during the Covid-19 epidemic, 338 or $85 \%$ of students do sports activities, and 71 or $15 \%$ of students do not do sports activities.

Table 2. Sport activities in the last 3 months

\begin{tabular}{llrr}
\hline No & Sport Activities in the Last 3 Months & Total & $\%$ \\
\hline 1 & Active to do sport activities & 221 & 48 \\
2 & Inactive to do sport activities & 238 & 52 \\
\hline Total & & 459 & 100 \\
\hline
\end{tabular}

Based on table 2 above, it shows that in the last 3 months, 221 or $48 \%$ of students are active in sports activities, and 238 or $52 \%$ of students do not do sports activities. Based on table 3 below, it shows that 168 or $37 \%$ of students sometimes do sports activities, 150 or $33 \%$ of students do 1 - 2 times sports activities, 80 or $7 \%$ of students do 2 - 3 times sports activities, and 61 or $13 \%$ of students do more than 3 times sports activities. 
Table 3. Sport activities in the last 3 months

\begin{tabular}{llrr}
\hline No & Sport activities in a week & Total & $\%$ \\
\hline 1 & Sometimes do sport activities & 168 & 37 \\
2 & $1-2$ times do sport activities & 150 & 33 \\
3 & $2-3$ times do sport activities & 80 & 17 \\
4 & More than 3 times do sport activities & 61 & 13 \\
\hline Total & & 459 & 100 \\
\hline
\end{tabular}

Table 4. Times to do sport activities

\begin{tabular}{llrr}
\hline No & Total of times to do sport activities & Total & $\%$ \\
\hline 1 & $0-30$ minutes to do sport activities & 245 & 53 \\
2 & $30-60$ minutes to do sport activities & 152 & 33 \\
3 & 60-90 minutes to do sport activities & 46 & 10 \\
4 & More than 120 minutes to do sport activities & 16 & 4 \\
\hline Total & & 459 & 100 \\
\hline
\end{tabular}

Based on table 4 above, it shows that the length of time in each sports activity, 245 or $53 \%$ of students do sports activities within 0-30 minutes, 152 or $33 \%$ of students do sports activities within $30-60$ minutes, 46 or $10 \%$ of students do sports activities within 60 - 90 minutes, and 16 or $4 \%$ of students do sports activities for more than 120 minutes.

Table 5. Times to do sport activities

\begin{tabular}{llrr}
\hline No & Types of Sport Activities Conducted & Total & $\%$ \\
\hline 1 & Swimming activities & 22 & 5 \\
2 & Athletics activities & 299 & 65 \\
3 & Gymnastics activities & 76 & 17 \\
4 & Biking activities & 10 & 2 \\
5 & Jogging activities & 52 & 11 \\
\hline Total & & 459 & 100 \\
\hline
\end{tabular}

Based on table 5 above, it shows that the types of sports activities carried out by students during the pandemic period 22 or $5 \%$ of students do swimming sports, 299 or $65 \%$ of students do game sports activities, 76 or $17 \%$ of students do gymnastics activities, 10 or $2 \%$ students do biking sports and 52 or $11 \%$ of students do jogging.

Table 6. Purpose to sport activities

\begin{tabular}{llrr}
\hline No & Purpose to sport activities & Total & $\%$ \\
\hline 1 & Maintain health & 341 & 74 \\
2 & Lose weight & 41 & 9 \\
3 & Hobby & 69 & 15 \\
4 & Etc & 8 & 2 \\
\hline Total & & 459 & 100 \\
\hline
\end{tabular}


Based on table 6 above, it shows that the purpose of doing sports activities is 341 or $74 \%$ of students do it with the aim of maintaining health, 41 or $9 \%$ of students do it with the aim of losing weight, 69 or $15 \%$ of students do it with the aim of a hobby and 8 or $2 \%$ of students do it for other purposes.

Table 7. Place to do sport activities

\begin{tabular}{llrr}
\hline No & Purpose to sport activities & Total & $\%$ \\
\hline 1 & Sport activities at home & 254 & 55 \\
2 & Sport activities in public facilities & 135 & 30 \\
3 & Sport activities in the field & 24 & 5 \\
4 & Sport activities in clubs & 20 & 4 \\
5 & Sport activities at school & 25 & 6 \\
\hline Total & & 459 & 100 \\
\hline
\end{tabular}

Based on table 7 above, it shows that where sports activities are done, 254 or $55 \%$ of students do sports activities at home, 135 or $30 \%$ of students do sports activities in public facilities, 24 or $5 \%$ of students do sports activities in the field, 20 or $4 \%$ of students do sports activities in clubs, and 25 or $6 \%$ of students doing sports activities at school.

\subsection{Discussion}

Based on the results of the research, it can be said that in general during the covid - 19 period where the learning process was carried out online, students of class XII SMKN 1 Tonjong Brebes regency continued to do sports. This certainly provides very good information, because class XII students who are about to graduate and are expected to work according to their competencies, have good physical fitness which is needed to be able to work well.

When it is viewed from sports activities during the pandemic, $85 \%$ of students do sports activities, $15 \%$ of students do not do sports activities. If you look at the sports activities that are carried out in the last 3 months, $48 \%$ of the students are active in sports activities, and $52 \%$ of the students do not do sports activities.

When it is viewed from the activities carried out every week $37 \%$ of students sometimes do sports activities, $33 \%$ of students do 1-2 times sports activities, $7 \%$ of students do 2 - 3 times sports activities, and $13 \%$ of students do more than 3 times. sports activity.

When it is viewed from the length of time spent doing sports activities, $53 \%$ of students do sports activities within 0-30 minutes, 33\% of students do sports activities within 30-60 minutes, $10 \%$ of students do sports activities within 60 - 90 minutes. minutes, and $4 \%$ of students do sports activities for more than 120 minutes.

When it is viewed from the type of sports activities carried out, $5 \%$ of students do swimming sports, $65 \%$ of students do game sports, $17 \%$ of students do gymnastics, $2 \%$ of students do biking sports activities and $11 \%$ of students do jogging sports activities.

When it is viewed from the goal of doing sports activities, $74 \%$ of students do it with the aim of maintaining health, $9 \%$ of students do it with the aim of losing weight, $15 \%$ of students do it for the purpose of a hobby and $2 \%$ of students do it with other purposes.

When it is viewed from the places where sports activities are carried out, $55 \%$ of students do sports activities at home, $30 \%$ of students do sports activities in public facilities, 
$5 \%$ of students do sports activities in the field, $4 \%$ of students do sports activities in clubs, and $6 \%$ students do sports activities at school.

\section{Conclusion}

Based on the results of research and discussion, it can be concluded that during the Covid19 pandemic, the twelfth grade students of SMK Negeri 1 Tonjong continued to do sports activities. Sports activities are conducted 1 to 3 times a week with implementation times ranging from 30 minutes to 120 minutes. The purpose of doing sports activities in general is to maintain health and some to lose weight and because of hobbies. Most of the sports activities conducted are athletics sports activities, and some of them are swimming, gymnastics, biking, and jogging. Most of the sports activities conducted are doing sports activities at home, some are carried out in public facilities, fields and in clubs.

\section{References}

[1] UU Nomor 20 Tahun 2003.

[2] Abdullah, A., \& Manadji A. Dasar- Dasar Pendidikan Jasmani. Jakarta: Departemen Pendidikan dan Kebudayaan.; 1994.

[3] http://hmeft.student.uny.ac.id/2017/04/.

[4] Muhajir. Pendidikan Jasmani Olahraga dan Kesehatan untuk Kelas X. Jakarta: PT Gelora Aksara Pratama.; 2007.

[5] Giriwijoyo, Y.S. S. et al. Ilmu Faal Olahraga. Bandung: PT Remaja Rosdakarya; 2012.

[6] https://www.kemdikbud.go.id.

[7] https://infeksiemerging.kemkes.go.id.

[8] Supriyanto, Dwi, Rahayu, T, Soegiyanto \& Rahayu S. Multifunction tools of physical education, sports and Health at elementaryschool. J Educ Dev. 2014;2 (1).

[9] Khamidi A. Pendidikan dan Strategi Belajar Mengajar. Surabaya: Unesa University Press.; 2008.

[10] Sejati, R., Kristiyanto A\& DM. Pengaruh Pendekatan Tradisional dan Pendekatan Pendidikan Gerak dalam Pembelajaran Penjasorkes terhadap Kebugaran Jasmani dan Kemampuan Memecahkan Masalah. J Media Ilmu Keolahragaan Indones. 2016; Volume 6.

[11] Kristyandaru A. Manajemen Pendidikan Jasmani dan Olahraga. Surabaya: Unesa University Press.; 2011.

[12] Muhajir. Pendidikan Jasmani Olahraga dan Kesehatan untuk Kelas X. Jakarta: PT Gelora Aksara Pratama; 2007.

[13] Irianto DP. Panduan Latihan Kebugaran yang Efektif dan Aman. Yogyakarta: Andi Offset.; 2000.

[14] Nurhasan. Tes dan Pengukuran dalam Pendidikan Jasmani. Jakarta: Departemen Pendidikan Nasional-Dirjen Dikdasmen; 2001.

[15] Irianto; Dj. P. Pedoman Praktis Berolahraga Untuk Kebugaran dan Kesehatan. Yogyakarta: Andi Offset.; 2004.

[16] Lutan R. Menuju Sehat dan Bugar [Internet]. Jakarta; 2002. Available from: Departemen Pendidikan dan Kebudayaan

[17] Retnoningsih S\& A. kamus Besar Bahasa Indonesia. Semarang: CV. Widya Karya; 2005.

[18] UU SKN No 3 Tahun 2005.

[19] http://e-journal.uajy.ac.id. 